\title{
Badania wartości ekonomicznej usług biblioteczno-informacyjnych i ich wpływu na otoczenie
}

\begin{abstract}
STreszczenie. Biblioteki pełnią różnorodne funkcje we współczesnym otoczeniu społecznym. Uczestniczą w tworzeniu kapitału intelektualnego i społecznego, wpływają na wzrost korzyści ekonomicznych użytkowników i całego społeczeństwa. W artykule omówiono główne podejścia i metody badawcze w zakresie oceny korzyści ekonomicznych płynących z funkcjonowania bibliotek. Skupiono się na metodzie analizy kosztów w stosunku do korzyści (ang. CBA - cost-benefit analysis), metodzie analizy warunkowej (ang. CVM - contigent valuation method), określaniu wartości dodanej dla użytkownika (ang. consumer surplus method) i metodologii oceny stopy wzrostu z inwestycji (ang. ROI - return of investment). Przeanalizowano również różne projekty badań prowadzone na świecie $\mathrm{w}$ tym zakresie.
\end{abstract}

SŁowA KLuczowe: badanie jakości bibliotek, ocena wpływu bibliotek na społeczeństwo, analiza korzyści ekonomicznych funkcjonowania bibliotek.

\section{Wstęp}

Potrzeba określania oraz przedstawiania społeczeństwu wartości ekonomicznej usług i produktów bibliotek zawsze była istotna. Tym bardziej w obecnych czasach, charakteryzujących się poważnymi redukcjami finansowania placówek bibliotecznych, dążenie do uświadamiania decydentom i ogółowi społeczeństwa ekonomicznych korzyści płynących z usług bibliotek staje się koniecznością. Wiele instytucji, także rządowych i związanych z kultura, prowadzi badania wartości ekonomicznej własnej działalności, korzystając z metod stosowanych przez firmy komercyjne, dostosowując je odpowiednio do specyfiki organizacji non profit.

Początkowe studia dotyczące analizy wartości finansowej oraz wpływu ekonomicznego bibliotek na otoczenie społeczne miały charakter teoretyczny. Jedną z najwcześniejszych prac przedstawiających podstawowe 
założenia określające analizę kosztów oraz korzyści finansowych dostarczanych przez biblioteki było studium R.H. Orra z 1973 roku$^{1}$. Autor przedstawił $\mathrm{w}$ nim opinię, że $\mathrm{w}$ takich badaniach należy analizować we wzajemnym powiązaniu następujące aspekty: zasoby biblioteki, ich jakość, wykorzystanie oraz wartość dla społeczeństwa². Dopiero jednak w 1996 roku Glen Holt i inni ${ }^{3}$ stworzyli metodologię pomagającą dokładniej przyjrzeć się czwartej z wymienionych płaszczyzn - pomiarowi korzyści z działalności biblioteki, skoncentrowanemu na zyskach lokalnych firm.

Do dziś wypracowano już sporo metod oceny efektywności ekonomicznej bibliotek oraz wieloaspektowej analizy ekonomicznych korzyści dla otoczenia płynących z ich funkcjonowania. Rozwój tej metodologii nastąpił głównie dzięki wielu pracom empirycznym, prowadzonym w różnych krajach, przede wszystkim w Stanach Zjednoczonych, Kanadzie i Wielkiej Brytanii. W badaniach adaptuje się często metodologię stosowaną $w$ innych rodzajach firm, dostosowując ją do specyfiki działalności instytucji biblioteczno-informacyjnych.

Można zauważyć, co podkreślają też liczni badacze ${ }^{4}$, że analizy te podążają w trzech kierunkach. Pierwszym rodzajem są badania oraz benchmarking efektywności kosztowej działalności biblioteki. Drugie podejście skupia się na pokazywaniu rezultatów ekonomicznych funkcjonowania biblioteki w społeczeństwie. Trzecie - będące rozwinięciem drugiego ukierunkowane jest na określanie rezultatów biblioteki w zakresie zwrotu finansowania, czyli obliczanie stopy zwrotu z inwestycji - ROI (return of investment). Dwa ostatnie podejścia łącznie pozwalają ocenić ekonomiczne korzyści wynikające z funkcjonowania bibliotek.

\section{Badania efektywności kosztowej}

Tego rodzaju analizy są najczęściej połączone z próbami ustalania możliwości podwyższania efektywności kosztów. Na świecie prowadzono je często w celu porównania przebiegu procesów oraz ich kosztów

${ }^{1}$ R.H. Orr, Measuring the goodness of library services: A general framework for considering quantitative measures, "Journal of Documentation” 1973, t. 29, s. 315-332.

2 Ibidem, s. 315.

${ }^{3}$ G.E. Holt, B.T. Fraser et al., Toward a Framework for Assessing Library and Institutional Outcomes, „College and Research Libraries” 1998, nr 6, s. 546-570.

${ }^{4}$ R. Missingham, Libraries and economic value: a review of recent studies, "Performance Measurement and Metrics" 2005, nr 3, s. 142; R. Dugan, P. Hernon, D. Nitecki, Viewing library metrics from different perspectives. Inputs, outputs and outcomes, Santa Barbara-Denver-Oxford 2009, s. 142-144. 
w różnych bibliotekach. Badania koncentrowały się również na ustalaniu najlepszych praktyk, jak np. w australijskim studium National Resource Sharing Working Group's study of ILL/DD and benchmarking studies and manuals for Australian university libraries.

W pomiarach efektywności kosztowej duże znaczenie ma koncepcja tzw. zrównoważonej karty wyników (ang. balanced scorecard), wywodząca się z metod księgowych, które posługiwały się prawie wyłącznie wskaźnikami finansowymi. Metoda balanced scorecard, zachowując finansowe wskaźniki efektywności, dodatkowo wprowadza do oceny czynniki określone z perspektywy klienta, procesów wewnętrznych oraz rozwoju. Założenia tej koncepcji znalazły odzwierciedlenie w najnowszych wydaniach dwóch podstawowych zbiorów wskaźników funkcjonalności bibliotek - normie ISO 11620 i w zaleceniach IFLA ${ }^{6}$. Perspektywy oceny, według balanced scorecard, dostosowano do badania bibliotek w następujaccych płaszczyznach: zasoby (w tym pracownicy, zbiory i infrastruktura), korzystanie z biblioteki, efektywność i wydajność oraz potencjał i rozwój.

Do wskaźników najczęściej powtarzających się we wspomnianych dokumentach należą:

- udział budżetu biblioteki w budżecie organizatora (\%),

- wydatki biblioteki w przeliczeniu na jednego użytkownika,

- wydatki na zbiory biblioteczne w przeliczeniu na jednego użytkownika,

- wydatki na zbiory elektroniczne jako procent wydatków na zbiory biblioteczne,

- przychody własne (specjalne dotacje, granty, fundusze wypracowane przez bibliotekę) w budżecie biblioteki (\%),

- wydatki na zbiory biblioteczne jako procent wydatków biblioteki,

- wydatki na płace i inne wydatki osobowe jako procent wydatków biblioteki ${ }^{7}$.

W najnowszej edycji normy ISO 11620:2008: Information and Documentation - Library Performance Indicators przedstawiono siedem wskaźników efektywności kosztów, które można wykorzystać w badaniach. Są nimi:

${ }^{5}$ Zob. raport R. Missingham, M. Moreno, Resource sharing in Australia: evaluation of national initiatives and recent developments, "Interlending and Document Supply" 2005, t. 33, nr 1, s. 26-34.

${ }^{6}$ R. Poll, P. te Boekhorst, Measuring quality: Performance measurement in libraries, München 2007 (IFLA Publications 127).

${ }^{7}$ L. Derfert-Wolf, M. Górski, A. Jazdon, Finansowanie bibliotek uczelni publicznych. Analiza wybranych wskaźników z lat 2002-2007, „Elektroniczny Biuletyn Informacyjny Bibliotekarzy" 2009, nr 8 (108). 
- Koszt Wypożyczenia,

- Koszt Sesji w Bazie Danych,

- Koszt Ściągniętego Dokumentu,

- Koszt w Przeliczeniu na Odwiedziny w Bibliotece,

- Stosunek Wydatków na Gromadzenie do Kosztów Personelu,

- Koszt w Przeliczeniu na Użytkownika,

- Wydatki na Zbiory Elektroniczne jako Procent Wydatków na Gromadzenie Informacji.

Obecnie na świecie istnieje bardzo wiele projektów benchmarkingowych, które służą ocenie i porównaniu funkcjonalności bibliotek. Dotyczą one wybranych typów bibliotek, np. naukowych lub publicznych, bądź obejmują biblioteki różnych rodzajów na terenie danego kraju czy regionu. Wykorzystują w dużej mierze wskaźniki ujęte we wspomnianych wyżej standardach. Najbardziej znana taka inicjatywa to BIX - Library Index, zainicjowana w 1999 roku w niemieckich bibliotekach publicznych, od 2002 obejmująca też biblioteki akademickie ${ }^{8}$. Z innych projektów można wymienić między innymi: fińską inicjatywę Finnish Public Libraries Statistics ${ }^{9}$, kanadyjską Canadian Public Library Statistics ${ }^{10}$, estońską Statistical database: Social life - Culture - Libraries ${ }^{11}$. Również w USA w ramach projektu LRS (Library Research Service) realizowana jest inicjatywa State Public Library Statistics ${ }^{12}$. We wszystkich projektach stosuje się również wskaźniki służące do porównań efektywności kosztowej bibliotek, przedstawiające w tym ujęciu zbiory i usługi zarówno tradycyjne, jak i elektroniczne.

W Polsce od 2001 roku prowadzony jest program Analiza funkcjonowania bibliotek naukowych - AFBN, obejmujaccy biblioteki naukowe i branżowe. Ponad 20 z 81 wszystkich wskaźników w projekcie to wskaźniki związane z finansami ${ }^{13}$. W fazie opracowania jest też projekt wskaźników benchmarkingowych dla bibliotek publicznych, w którym również znajdą się wskaźniki dotyczące efektywności kosztów ponoszonych w związku ze świadczeniem usług i dostarczaniem zasobów tradycyjnych i elektronicznych.

\footnotetext{
${ }^{8}$ http://www.bix-bibliotheksindex.de/index.php?id=2.

${ }^{9}$ http://tilastot.kirjastot.fi/en-GB/.

${ }^{10} \mathrm{http}: / /$ www.culc.ca/research/kpis/.

${ }^{11}$ http://pub.stat.ee/px-web.2001/I_Databas/Social_Life/01Culture/10Libraries/10Libraries.asp.

${ }^{12}$ http://www.lrs.org/public/other.php.

${ }^{13}$ Wykaz wskaźników funkcjonalności bibliotek i danych obliczanych w ramach projektu AFBN, które są analizowane zbiorczo i publikowane każdego roku (2011; dla danych z ankiet z 31 grudnia 2010 roku), http://ssk2.bu.amu.edu.pl/standaryzacja/.
} 


\section{Ocena korzyści ekonomicznych płynących $\mathrm{z}$ funkcjonowania bibliotek}

Ocena wartości ekonomicznej biblioteki nie jest, jak we wcześniej omówionym podejściu, badaniem i porównywaniem kosztów jej działalności. Przyjmuje się w niej perspektywę oceny utraconych korzyści finansowych społeczeństwa w przypadku likwidacji biblioteki. Takie bezpośrednie korzyści są różnorodne. Zalicza się do nich przede wszystkim:

- korzyści indywidualne - np. oszczędności z tytułu wypożyczenia materiałów, które w innym wypadku trzeba by kupić, dostęp do bezpłatnego kształcenia informacyjnego,

- korzyści dla lokalnych firm - np. w postaci dostępu do baz danych z dziedziny prawa i podatków,

- korzyści dla lokalnej społeczności - bezpłatny dostęp do informacji i kultury.

Jak wcześniej wspomniałam, takiej oceny próbuje się dokonywać, pokazując rezultaty ekonomiczne funkcjonowania biblioteki w społeczeństwie i określając stopę zwrotu z inwestycji - ROI.

Przyjrzyjmy się najpierw pierwszemu z dwu wymienionych podejść. Sposoby prowadzenia badań rezultatów ekonomicznych działalności biblioteki są bardzo różnorodne. Często stosowaną metodą jest analiza kosztów w stosunku do korzyści (ang. CBA - cost-benefit analysis). Określanie tych relacji nie jest łatwe. $W$ ramach takich studiów wykorzystuje się przede wszystkim metodę wyceny warunkowej (ang. CVM - contigent valuation method), w której klienci deklarują swoje chęci w zakresie odpłatności za usługi, np. zamiar płacenia więcej niż cena rynkowa, jeśli usługi są dopasowane do ich potrzeb ${ }^{14}$. W ramach wyceny warunkowej najczęściej stosowane są dwa podejścia: ocena willingness to pay (WTP), w której respondent jest pytany, ile zdolny byłby zapłacić za produkt lub usługę biblioteczno-informacyjną na wolnym rynku, oraz ocena willingness to accept (WTA), w której badany wskazuje na akceptowany przez siebie poziom kosztów, jakie chciałby ponieść, by utrzymać określone usługi bibliotek. Główną trudnością związaną ze stosowaniem CVM jest konieczność przyjęcia założenia o pełnej znajomości oferowanych produktów i usług wśród osób badanych, co nie zawsze jest spełnione. Lepiej jest więc zamiast prowadzić badania w całej populacji użytkowników biblioteki skoncentrować się na opiniach ekspertów.

Jeszcze jednym z proponowanych sposobów oceny korzyści jest określenie wartości dodanej dla użytkownika (ang. consumer surplus): klienci

${ }^{14}$ R. Dugan, P. Hernon, D. Nitecki, op.cit., s. 142-144. 
są proszeni o określenie wartości każdej dostarczanej przez bibliotekę usługi. Jest to podejście bardzo podobne do wyceny warunkowej; różnica polega na tym, że w consumer surplus dąży się do ustalenia zależności między poziomem świadczeń klienta (np. w postaci podatków) a koszta$\mathrm{mi}$, jakie chce ponosić za usługi ${ }^{15}$.

Badania rezultatów ekonomicznych funkcjonowania biblioteki w środowisku społecznym skupiają się zatem przede wszystkim na określaniu kosztów kalkulacyjnych (ang. proxy prices, shadow prices), czyli kosztów, które trzeba ponieść za takie same usługi, jakie świadczy biblioteka, lecz na wolnym rynku. Kalkulację proxy prices (shadow prices) w odniesieniu do usług bibliotek szerzej przedstawiła Roswitha Poll ${ }^{16}$. Pierwsze badania bazujące na omawianej metodologii były prowadzone w 1999 roku w bibliotekach publicznych i specjalnych: St. Louis Public Library; King County Library System, Seattle; Baltimore County Public Library; Birmingham Public Library, Alabama i Phoenix Public Library ${ }^{17}$. W bibliotece w St. Louis pytano użytkowników o sumę, o jaką zgodziliby się zwiększyć swój podatek, aby nie zamykać bibliotek $w$ regionie. Pytano również o to, jaka kwota zmniejszenia podatku rekompensowałaby im zamknięcie bibliotek. W badaniach prowadzonych na przykład dla bibliotek publicznych w Wielkiej Brytanii na początku XXI wieku użytkownicy szacowali wartość wypożyczenia poszczególnych książek (cenę, jaką chcieliby zapłacić za transakcję). Średnia cena transakcji została porównana ze średnią ceną zakupu. Podobne badania prowadzono również między innymi w bibliotekach publicznych w Norwegii, w bibliotekach uniwersyteckich i publicznych w Kanadzie, w Bibliotece Brytyjskiej, a także oceniano wpływ ekonomiczny National Bibliographic Database i National Union Catalogue of the National Library w Nowej Zelandiii ${ }^{18}$. Inny, choć rzadko stosowany w praktyce, sposób obliczania proxy prices to analiza ilości czasu spędzanego przez użytkowników na korzystaniu z usług bibliotecznych. Liczba godzin jest tu pomnożona przez średni zarobek użytkownika na godzinę ${ }^{19}$.

W szacowaniu wpływu ekonomicznego biblioteki nie należy też pomijać oceny bezpośredniego wpływu jej usług na finanse instytucji

15 P.J. Calvert, Assessing the effectiveness and quality of libraries, a thesis submitted to the Victoria University of Wellington [online], [dostęp: 18.05.2011], dostępny w internecie: http://researcharchive.vuw.ac.nz/bitstream/handle/10063/.../thesis.pdf.

${ }^{16}$ R. Poll, Impact/Outcome Measures for Libraries, „LIBER Quarterly" 2003, nr 3/4, s. 329 .

17 Ibidem.

18 R. Missingham, op.cit., s. 144-146.

${ }^{19}$ R. Poll, op.cit., s. 336-338. 
macierzystej bądź społeczności lokalnej (np. na uzyskane granty, dotacje, lepiej płatną pracę) $)^{20}$.

\section{Ocena stopy zwrotu z inwestycji - ROI}

W latach 90. XX wieku zainteresowano się szerszą perspektywą badań korzyści ekonomicznych tworzonych przez biblioteki, co zwróciło uwagę na możliwość wykorzystywania metody balanced scorecard utworzonej przez Roberta S. Kaplana i Davida P. Nortona. Oznaczało to analizę funkcjonowania bibliotek w czterech perspektywach: finansowej (także zwrotu z inwestycji), klientów, procesów wewnętrznych i pracowników. To zapoczątkowało upowszechnienie metodologii ROI, którą najczęściej łączono z wcześniej omawianą metodą CVM i określaniem kosztów kalkulacyjnych.

Koncepcja ROI została zastosowana w badaniu instytucji non profit w 1993 roku, kiedy to w USA odbyła się dyskusja panelowa dotyczacca ochrony środowiska i metod oceny wartości tej ochrony. W odniesieniu do bibliotek jest to metodologia ukazująca finansowe implikacje związane $\mathrm{z}$ istnieniem bądź nieistnieniem usług biblioteczno-informacyjnych. Przy jej wykorzystaniu otrzymuje się wskaźnik rentowności inwestycji, czyli - w wypadku bibliotek - stosunek utraconych korzyści w przypadku likwidacji biblioteki do nakładów finansowych przeznaczonych na jej funkcjonowanie. Metodologia ROI najlepiej przedstawiona jest w sprawozdaniach projektu LRS (Library Research Service) o nazwie Public Libraries - A Wise Investment ${ }^{21}$. Wzór na wskaźnik rentowności wygląda w nich następująco:

ROI to:

- koszt alternatywnych rozwiązań (Cost to Use Alternatives)

- + utrata usług i informacji (Lost Use)

- + bezpośrednie wydatki lokalne (Direct Local Expenditures)

- + kompensacja strat dla personelu (Lost Compensation for Library Staff)

- + utracone zyski innych firm (Halo Spending)

- podzielone przez zainwestowane środki.

Koszt alternatywnych rozwiązań to szacunkowe wydatki, jakie trzeba ponieść za takie same usługi, jakie świadczy biblioteka, lecz na wolnym rynku. Utrata usług i informacji to szacunkowa wartość dla użytkowników

\footnotetext{
${ }^{20}$ Ibidem.

${ }^{21}$ LRS. Return on Investment for Public Libraries [online], [dostęp: 19.05.2011], dostępny w internecie: http://www.lrs.org/public/roi/.
} 
informacji i usług informacyjnych, których nie można uzyskać gdzie indziej (np. wiele usług reference service). Bezpośrednie wydatki lokalne to straty, jakie poniosą lokalne firmy w przypadku likwidacji biblioteki. Chodzi o firmy prowadzące działalność gospodarczą na terenie biblioteki oraz usługodawców biblioteki (np. firmy dostarczające zasoby informacyjne, konserwatorów sprzętu komputerowego, urządzeń). Niewątpliwie istnienie i funkcjonowanie biblioteki ma pośredni wpływ na wyniki ekonomiczne firm działających $w$ jej otoczeniu. Kompensacja strat dla personelu to wydatki z budżetu z tytułu zwolnień i powiększania bezrobocia, a utracone zyski innych firm to straty przedsiębiorstw $\mathrm{z}$ otoczenia biblioteki, z których usług korzystają użytkownicy w drodze do niej (np. restauracje, sklepy) $)^{22}$. Według badań z 1997 roku wskutek zamknięcia biblioteki nastąpiłoby około 23-procentowe ograniczenie takich zysków ${ }^{23}$. Prawdopodobnie obecnie, ze względu na dostępność usług biblioteczno-informacyjnych online, wspomniane skutki ekonomiczne byłyby mniejsze.

Na witrynach internetowych różnych inicjatyw badania wpływu ekonomicznego i na stronach wielu bibliotek amerykańskich znajdują się też proste kalkulatory wartości usług bibliotecznych ${ }^{24}$.

Dla doskonalenia metodologii w zakresie omawianego rodzaju badań bardzo ważny okazał się projekt realizowany przez biblioteki publiczne stanu Floryda. Wstępne badania zostały przeprowadzone w 2000 roku przez The Information Use Management and Policy Institute in the School of Information Studies, Florida State University. Głównym celem było określenie korzyści ekonomicznych przynoszonych przez biblioteki publiczne swoim użytkownikom oraz społeczności lokalnej i szerszemu otoczeniu. Zespół badawczy rozwinął i przetestował także metodologię ROI w odniesieniu do bibliotek publicznych. ROI jest wskaźnikiem pokazującym zyski z zainwestowanych nakładów - w odniesieniu do bibliotek pokazuje wartość usług i produktów biblioteki w porównaniu z jej rocznym budżetem.

Kolejne badania, które miały wpływ na metodykę dalszych analiz ROI, prowadzono w latach 1999-2002 w stanie Północna Karolina. Dotyczyły

${ }^{22}$ N. Steffen et al., Public Libraries - A Wise Investment. A Return on Investment Study of Colorado Libraries, March 2009, s. 6 [online], [dostęp: 20.07.2011], dostępny w internecie: http://www.lrs.org/documents/closer_look/roi.pdf; zob. też np. Public Libraries - A Wise Investment. Cortez Public Library [online], [dostęp: 15.05.2011], dostępny w internecie: http://www.lrs.org/documents/roi/cortez.pdf.

${ }^{23}$ R. Proctor, B. Usherwood, G. Sobczyk, What Happens When a Public Library Service Closes Down?, „Library Management” 1997, nr 1, s. 59-64.

${ }^{24}$ Zob.np. Indiana Libraries and Library Statistics [online], [dostęp: 20.05.2011], dostępny w internecie: http://www.stats.indiana.edu/LibraryValuationCalculator.xls; zob. też załącznik nr 1 do artykułu. 
one przeżyć i doświadczeń klientów w czasie korzystania z drogi widokowej Blue Ridge Parkway. Skupiono się na kilku rodzajach korzyści:

- wartości wykorzystania (use value) - gotowości płacenia za świadczone obecnie usługi,

- wartości opcjonalnej (option value) - gotowości płacenia za możliwość wykorzystania usług w przyszłości,

- wartości istnienia usług (existence value) - gotowości płacenia za istnienie usług, jeśli nawet nie rozważa się przyszłego ich wykorzystania,

- wartości spuścizny (bequest value) - gotowości płacenia za oferowanie usług przyszłym pokoleniom ${ }^{25}$.

Wskaźniki te zostały wykorzystane w dalszych badaniach prowadzonych w bibliotekach.

W 2004 roku powrócono do wspomnianych wcześniej badań na Florydzie. W Center for Economic Development Research University of South Florida przeprowadzono wiele analiz, których celem była ocena wpływu ekonomicznego różnych instytucji działających na Florydzie, m.in. szpitali, zoo, H. Lee Moffitt Cancer Center and Research Institute. Badano istniejące w poszczególnych instytucjach miejsca pracy, zarobki pracowników oraz wartość świadczonych usług.

Badania prowadzone na Florydzie objęły także biblioteki publiczne. Ich przedmiotem było wykorzystanie bibliotek i ich usług, koncentrowano się tu również na analizie usług zdalnych, szczególnie na uzyskaniu informacji o ostatnio wykorzystywanych takich usługach i powodach ich popularności. Ważnym celem badań było też określenie znaczenia informacji i usług dostarczanych przez biblioteki w nawiązywaniu relacji między użytkownikami. Pytano również o sposoby wykorzystania informacji oraz koszty korzystania z usług biblioteki publicznej. Starano się znaleźć odpowiedź na pytanie, jakie działania podjęliby użytkownicy, gdyby nie istniały biblioteki publiczne. Analizowano także korzystanie z bibliotek przez dzieci. Bazowano na trzech rodzajach źródeł danych: informacjach pochodzących od użytkowników (także zdalnych), analizie wykorzystania biblioteki, jej usług i zasobów oraz wywiadach telefonicznych z przedstawicielami organów - właścicielami bibliotek. Ważną częścią omawianych badań była analiza ROI obejmująca okres od grudnia 2003 roku do sierpnia 2004 roku $^{26}$.

${ }^{25}$ Workshop to Discuss Return on Taxpayer Investment in Public Libraries in Florida [online], [dostęp: 20.05.2011], dostępny w internecie: dlis.dos.state.fl.us/bld/roi/workshop/handouts/ROI_Workshop_Introduction.pdf

${ }^{26}$ J.M. Griffiths, K. King, T. Lynch, Taxpayer return on investment in Florida public libraries: Summary report. 2004 [online], [dostęp: 20.05.2011], dostępny w internecie: http://dlis.dos.state.fl.us/bld/roi/RFP.cfm. 
W 2004 roku przeprowadzono badania ROI w British Library. Przebadano w nich ponad 2000 osób. Starano się określić:

- willingness to pay, pytając o ewentualne koszty, jakie użytkownicy chcieliby ponosić za dostęp do usług bibliotecznych,

- willingness to accept, badając akceptowany przez użytkowników poziom kosztów, jakie chcieliby ponieść, by utrzymać określone usługi biblioteki,

- investment in access, oceniając koszty i czas zainwestowany w usługi,

- cost of alternatives, ustalając koszty materiałów i usług alternatywnych,

- price elasticity, określając zmianę wymagań w związku ze zmianą kosztów.

Z badań wynika, że wskaźnik rentowności British Library wynosi 4,427. Jednym z największych projektów badawczych w omawianym zakresie była inicjatywa Public Libraries - A Wise Investment zainicjowana wiosną 2006 roku. Jej celem było określenie korzyści, jakie przynoszą społeczeństwu biblioteki publiczne, oraz obliczenie stopy zwrotu środków publicznych zainwestowanych w biblioteki. W maju 2006 roku organizacja Library Research Service (LRS) rozpoczęła badania What's It Worth to You? A Return on Investment Study of Selected Colorado Public Libraries. Wykorzystano w nich metodę studiów przypadków. Przeanalizowano wpływ ekonomiczny ośmiu bibliotek publicznych stanu Kolorado. Dobrano je w taki sposób, aby utworzyć próbę reprezentatywną pod względem geograficznym, demograficznym i ekonomicznym dla bibliotek regionu. Przebadano: Cortez Public Library, Denver Public Library, Douglas County Libraries, Eagle Valley Library District, Fort Morgan Public Library, Mesa County Public Library District, Montrose Library District i Rangeview Library District. Zastosowano różnorodne techniki zbierania informacji. Były nimi przede wszystkim ankiety i wywiady, posłużono się także dokumentacją biblioteczną. Grupa ankietowanych użytkowników bibliotek liczyła prawie 5000 osób. Ponadto przeprowadzono wiele wywiadów z bibliotekarzami dotyczących świadczonych przez nich usług oraz z członkami społeczności obsługiwanej przez biblioteki na temat wartości ekonomicznej usług. Zebrano również dane dotyczące zarobków personelu bibliotek. Dla większości przebadanych bibliotek stopa zwrotu (ROI) mieściła się w granicach pięciu (oznacza to pięciokrotną wartość zainwestowanego kapitału) ${ }^{28}$.

${ }^{27}$ British Library. Measuring our value. Results of an independent economic impact study commissioned by the British Library to measure the Library's direct and indirect value to the UK economy [online], [dostęp: 20.07.2011], dostępny w internecie: http://www.bl.uk/ aboutus/stratpolprog/increasingvalue/publicvalue/value.pdf.

${ }^{28}$ N. Steffen et al., op.cit., s. 12; zob. też załącznik nr 2. 
Do 2009 roku w Stanach Zjednoczonych przeprowadzono dziesięć obszernych projektów badawczych zgodnie z metodologią ROI. Objęto nimi biblioteki publiczne stanów Floryda, Pensylwania i Kolorado, w których informacje do ustalania stopy zwrotu kapitału zbierano, wykorzystując podejście CVM, oraz stanów Vermont, Południowa Karolina, Wisconsin, Nowy Jork, Ohio, Pittsburgh i Indiana, w których wykorzystano badania marketingowe, analizując głównie koszty alternatywnych rozwiązań. Okazało się, że pierwsza metoda zbierania danych jest efektywniejsza, pozwala uzyskać pełniejsze informacje - ukazuje bardziej kompleksowo ekonomiczny wpływ bibliotek na otoczenie społeczne. Średnia stopa zwrotu we wszystkich przebadanych przypadkach wyniosła 4,52, a mediana $4,06^{29}$.

Biblioteki akademickie mniej interesują się badaniem swojego wpły$\mathrm{wu}$ na środowisko społeczne $\mathrm{w}$ aspekcie ekonomicznym, rzadziej też ustalają ROI. Wynika to z innych warunków ich funkcjonowania i faktu, że stanowią ważny i niezbędny element uczelni. Niemniej niedostatki w finansowaniu szkół wyższych i ich bibliotek coraz częściej skłaniają do koncentrowania się również na takich analizach. Najczęściej jednak zainteresowanie badaniami ROI powstaje w momencie konieczności analizy rentowności zainwestowanych funduszy pochodzących z grantów. Takie badania realizowano między innymi w ramach inicjatywy The Lib-Value Project, szczególnie drugiej fazy projektu: University Investment in the Library, Phase II: An International Study of the Library's Value to the Grants Process, podczas której przebadano osiem bibliotek w ośmiu krajach na różnych kontynentach pod kątem wykorzystania funduszy z grantów i stopy ich zwrotu. Badania te przeprowadzono w University of Illinois at Urbana-Champaign (UIUC) w 2008 roku $^{30}$.

Ze względu na inną specyfikę funkcjonowania bibliotek akademickich, częściowo odmienne ich funkcje oraz krąg użytkowników w porównaniu z bibliotekami publicznymi, metodologia i zakres badań ich wpływu ekonomicznego na otoczenie powinny uwzględniać te różnice. Metodologię taką wypracowuje się $\mathrm{w}$ ramach projektu The Lib-Value, jego trzeciej części: The Lib-Value Values, Outcomes, and Return on Investment of Academic Libraries, finansowanej z grantu Institute of Museum and Library Services (IMLS), a prowadzonej od 1 grudnia 2009 do 30 stycznia 2012 roku.

\section{${ }^{29}$ Ibidem, s. 7.}

${ }^{30}$ C. Tenopir et al., University Investment in the Library, Phase II: An International Study of the Library's Value to the Grants Process, 2010 [online], [dostęp: 19.05.2011], dostępny w internecie: http://libraryconnect.elsevier.com/whitepapers/roi2/2010-06whitepaper-roi2.pdf. 
Omawiany, będący w trakcie realizacji projekt badawczy koncentruje się na trzech głównych obszarach funkcjonowania bibliotek akademickich oraz ich instytucji macierzystych: dydaktyce, badaniach naukowych i funkcjach publicznych. Szczegółowe cele inicjatywy obejmują:

- utworzenie modeli kalkulacji wartości i ROI bibliotek akademickich,

- utworzenie narzędzi sieciowych służących do takich badań,

- przetestowanie modeli i narzędzi w trzech bibliotekach.

Jak widać, tego rodzaju badania i ich metodologia w bibliotekach akademickich są dopiero w początkowym stadium rozwoju.

\section{Zakończenie}

Wartość funkcjonowania bibliotek oraz ich wpływ na otoczenie społeczne można rozpatrywać w wielu aspektach - ich roli dydaktycznej i naukowej, kulturalnej i informacyjnej, a także społecznej w środowisku lokalnym (np. ograniczanie wykluczenia różnych grup społecznych, miejsce spotkań i inicjatyw społecznych).

Nie należy też zapominać o aspekcie ekonomicznym funkcjonowania bibliotek. Pod tym względem analizy mogą być prowadzone na dwóch płaszczyznach: oceny kosztów i ich efektywności oraz badaniu wartości ekonomicznej bibliotek dla społeczeństwa. Obliczanie wskaźników efektywności kosztowej i prowadzenie benchmarkingu w tym zakresie są ważne, gdyż pokazują wykorzystanie środków i ułatwiają planowanie oraz ocenę działań. Jednak wprowadzenie do badań omówionej $\mathrm{w}$ artykule perspektywy utraconych korzyści finansowych społeczeństwa w przypadku likwidacji bibliotek pozwala ujrzeć ich funkcjonowanie w zupełnie innym świetle. Dzięki niej można dostrzec i pokazać, że biblioteki nie tylko pochłaniają społeczne fundusze oraz generują koszty, lecz również przyczyniają się do tworzenia korzyści finansowych. Należy zwracać na to uwagę i uświadamiać ten aspekt wartości bibliotek władzom decydującym o ich finansowaniu, użytkownikom i społeczeństwu.

Dostosowana do specyfiki badań bibliotek metodologia ROI i praktyczne jej realizacje $\mathrm{w}$ wielu bibliotekach pokazują sposoby prowadzenia takich analiz i ocen z innej ważnej perspektywy, która jest nowa, w Polsce mało znana, a obecnie mocno podkreślana w światowym bibliotekarstwie. Jest też bardzo kompleksowa i trudna w realizacji i interpretacji wyników. Badania takie jednak mają dużą wartość - ujmują funkcjonowanie bibliotek w środowisku społecznym wieloaspektowo i wskazują na możliwe korzyści oraz wartości ekonomiczne różnorodnych usług 
bibliotecznych. Przyczyniają się też do poznania opinii użytkowników na temat tego aspektu korzystania $\mathrm{z}$ bibliotek.

\section{Załącznik 1. Kalkulator ROI (przykład)}

Individual Return on Investment Calculator (http://www.lrs.org/public/roi/usercalculator.php)

\section{Which Colorado library do you visit?}

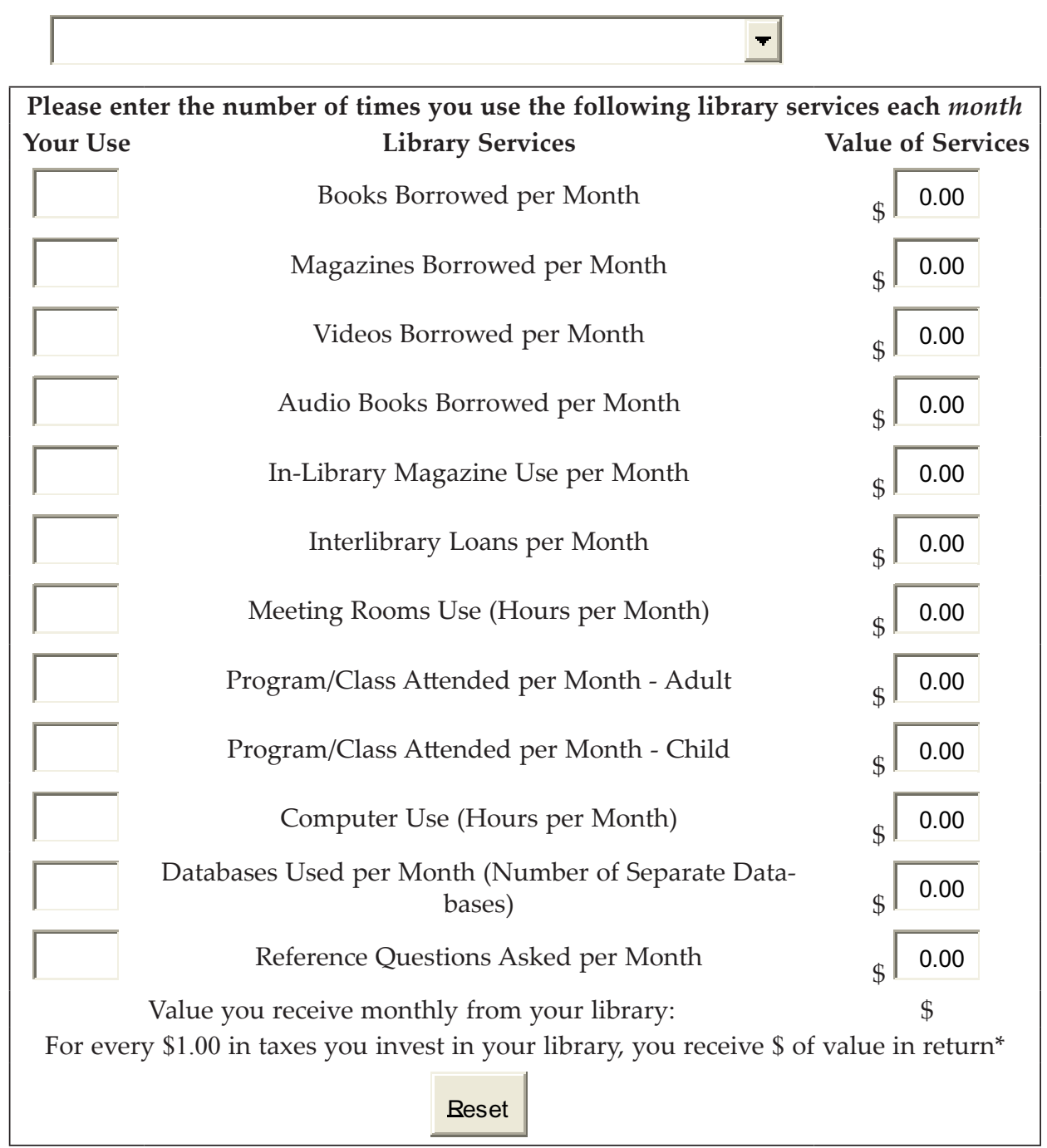




\title{
Załącznik 2. Raporty z badań metodologią ROI (Projekt Colorado Association of Libraries Wise Investement - 2005-2007)
}

Cortez Public Library - http://www.lrs.org/documents/roi/cortez.pdf Denver Public Library - http://www.lrs.org/documents/roi/denver.pdf Douglas County Libraries - http://www.lrs.org/documents/roi/douglas.pdf Eagle Valley Library District - http://www.lrs.org/documents/roi/eagle.pdf Fort Morgan Public Library - http://www.lrs.org/documents/roi/ftmorgan.pdf

Mesa County Public Library District - http://www.lrs.org/documents/roi/ mesa.pdf

Montrose Library District - http://www.lrs.org/documents/roi/montrose.pdf Rangeview Library District - http://www.lrs.org/documents/roi/rangeview

\section{EWA GŁOWACKA}

\section{Library and information services economic impact research and their impact on the surroundings}

\begin{abstract}
Aвstract. Libraries play different important roles in contemporary society. They contribute to advancement of intellectual and social capital and have a particular impact on economic benefits of their surroundings. This paper gives an overview of the main approaches to library economic impact research. These include: cost effectiveness research, CBA - cost-benefit analysis, CVM - contigent valuation method, consumer surplus method and ROI (Return of Investment). In addition, the author analyses different available research initiatives in this area.
\end{abstract}

KEY WORDs: library economic impact research, evaluation of the library impact on society, library cost-effectiveness analysis, methods, description of selected research studies. 